\title{
ANALYSIS OF MOTHERS' SELF-CONTROL OF SPENDING FOR THEIR OWN AND THEIR KIDS ${ }^{1,2}$
}

\author{
Miray Baybars ${ }^{3} \quad$ Ayla Özhan Dedeoğlư
}

\begin{abstract}
Women receive help from a variety of products and services to facilitate the transition to motherhood identity. Consumer self-control can be evaluated in different areas such as food consumption, emotional responses, consumer spending etc. It is expected that the analysis of self-control in expenditures of mothers, an important consumer group, will reveal important findings for the extremely large and still developing mother-child market. In this context, the aim of the research is to determine how the consumption selfcontrol of consumers varies in different situations (eg for the person and the child). The mothers were found to be a promising sample for clarifying the research question due to the fact that they spend for both themselves and their children. Mothers who contributed to the study as participants were reached through the active mothers groups on Facebook. It can be stated that the most important contribution of the study to the literature is that it shows that the consumer behaves differently in terms of spending self-control and subdimensions depending on the context.
\end{abstract}

Keywords: Mothers, Self-Control, Consumer Spending Self Control

JEL Classification: M31, M39

\section{ANNELERIN HARCAMA ÖZ-KONTROLÜNÜN KENDILERI VE ÇOCUKLARI IÇîN INCELENMESi}

Öz

Kadınlar annelik kimliğine geçişi kolaylaştırmak için çeşitli ürün ve hizmetlerden yardım almaktadırlar. Tüketici öz-kontrolü yiyecek tüketimi, duygusal tepkiler, odaklanma ve harcamalar gibi farklı alanlarda değerlendirilebilmektedir. Önemli bir tüketici grubu olan annelerin harcamalarındaki öz-kontrolünün analizinin hâlihazırda son derece büyük ve halen gelişmekte olan anne-çocuk pazarı için önemli bulgular ortaya koyacağı beklenmektedir. Bu bağlamda araştırmanın amacı anneler özelinde tüketicilerin harcama özkontrolünün farklı durumlarda (örneğin kişinin kendisi ve çocuğu için) ne şekilde farklılaştığının ortaya konmasıdır. Anneler hem kendileri hem de çocukları için harcama yaptıklarından dolayı araştırma sorusunun aydınlatılması açısından uygun bulunmuşlar, araştırmanın örneklem grubu olarak bu sebeple belirlenmişlerdir. Çalışmaya katılımcı olarak katkıda bulunan annelere Facebook'ta aktif olan anne grupları üzerinden ulaşıımıştır. Çalışmanın literatüre en önemli katkısının tüketicinin harcama öz-kontrolü ve alt boyutları açısından durumsal olarak farklı davrandığını göstermesi olduğu ifade edilebilir.

Anahtar Sözcükler: Anneler, Öz-Kontrol, Tüketici Harcama Öz-Kontrolü

JEL SInıflandırması: M31, M39

\footnotetext{
${ }^{1}$ Bu proje Ege Üniversitesi Bilimsel Araştırma Projeleri Koordinatörlüğü tarafından 18-iKT-003 kodu ile desteklenmektedir. Desteklerinden ötürü yazarlar Ege Üniversitesi Bilimsel Araştırma Projeleri Koordinatörlügü̈ne teşekkürlerini sunarlar. This project is supported by Ege University Scientific Research Projects Coordination Unit with project number 18-iKT-003. Authors would like to thank Ege University Scientific Research Coordination Unit for their support.

${ }^{2}$ This study was presented in PPAD Marketing Congress 2019, which was held on May 1-4, 2019 in Kuşadası-Aydin.

3 Res. Asst. Dr., Ege University, Faculty of Economics and Administrative Sciences, Department of Business, miray.baybars@ege.edu.tr, ORCID:0000-0002-8494-6770

4 Prof. Dr., Ege University, Faculty of Economics and Administrative Sciences, Department of Business, ayla.dedeoglu@ege.edu.tr, ORCID:0000-0002-0179-0644
}

DOI: $10.18092 /$ ulikidince.582720 


\section{Introduction}

The importance of the role of consumption in the construction and negotiation of motherhood identity following pregnancy is expressed in various studies (Clarke, 2004; Ogle et al., 2013; Andersen et al., 2008). In consumer culture, consumers use mythic and symbolic resources provided by the marketplace to construct meanings, practices and narratives of identity and create a unity between themselves and community through authenticating acts and authoritative performances (Arnould and Thompson, 2005; Arnould and Price, 2000). In addition to selfdetermination process, women use consumption to facilitate their identity transition to motherhood (e.g. Banister and Hogg, 2006). The marketplace is characterised with the profusion of the consumer products that vary in form of basic breast pads and baby formulas to early foreign language classes for babies and toddlers.

In many developed and developing markets, expenditures on children by families have enormously increased as the size of motherhood and childcare marketplaces expanded (Lino et al., 2017). Mothers, being the most important subjects of this market along with the companies operating within, need to be analyzed to be understood in detail, in order to predict, project and respond to their needs and wants accordingly. Understanding the consumption practices of mothers, their purchase motivations and the factors that may cause hesitation is important for predicting the future trends of motherhood and childcare market.

In addition to pre-purchase, purchase and post-purchase phases of consumer behavior (Solomon, 2018), the constructs related with non-spending also deserves to be questioned to illuminate the consumer behavior processes as a whole. Consumer self-control can be analyzed in diverse domains such as financial control and eating control or in relation to emotions, attentions, thoughts and impulses (Tuk et al., 2015). Consumer spending self-control can be thought as a construct derived from the construct of self control; the only difference is that relates to consumers' self-control of their expenditures. Although there is evidence supporting a correlation between general self-control and domain-specific self-control of individuals (Muraven et al., 2006), measurement of consumer spending self-control is found to have better discriminant and predictive validity compared to self-control of general behavior (Haws et al., 2014). Although there are studies that reveal how consumer self-control varies across different domains, there still remains a lack of research that analyze how a consumer's self-control of spending may change in situations when the decision-maker and users are not the same person. Since mothers give consumption decisions on behalf of their own and, also, their children, an analysis of mothers' consumer spending self-control may help to develop new theoretical explanations by shedding a light on consumer spending self-control of the individual depending on different modes of relation to oneself and others, and in different contexts.

Scholarly studies has revealed that the child is part of mothers' extended self and display of self-identity (McNeill and Graham, 2014, Hughes, Kaigler-Walker and Bendoni, 2015; ÖzhanDedeoğlu, 2010). In the process of constructing a motherhood identity, women extend their self so as to include the child as a major part. In his seminal study, Belk (1988) remarked that "other people" can contribute to one's understanding of who (s)he is and, particularly, children represent an extension of self and even carry over this representation beyond the parents' deaths. For a mother, consumption and purchase decisions on behalf of her children is still related to their own self-identity.

In addition to a mother's attempt to shape the child's identity through consumer socialization in the marketplace, children also make a mother; since consumption on behalf of children help women to construct their motherhood identity (Banister and Hogg, 2006). While Thomsen and Sorensen (2006) supported the idea that transition to motherhood identity is experienced by using the symbolic and material resources provided by the marketplace, studies revealed that, to impress others in their social network, mothers can construct their relational identity through purchasing premium items for their children, even when children cannot notice and appreciate it (Silhouette- 
Dercourt and Lassus, 2016; Ozhan Dedeoglu, 2010). Therefore, mothers, as a market agent who make consumer decisions both on behalf of themselves and their children, are worthy for an analysis due to their potential for providing theoretical explanations for the research question whether consumer spending self-control of the same person changes depending on different modes of relation to oneself and others -i.e. in different contexts- or not.

\section{Consumer Spending Self-Control}

Consumers are not necessarily rational market agents; driven by a few generative principles, they can confuse spheres and apply the same schemes to different logical universes and, thus, develop a logic of practice that results in a loss of rigour for the sake of greater simplicity and generality (Bourdieu, 1977:110). Therefore, rather than evaluating the consumer behavior in terms of only reasoned actions or emotional conduct, it would be better to consider emotional, cognitive and other relevant perspectives together (Hoffman et al., 2008). Although research evidence shows that, in general, wants and desires and subsequent actual purchase decisions are related, self-control can moderate the relationship; self-controlling the passionate desires for a market offer, a consumer's actual choice may be quite different from the motivating feelings (Sela, Berger and Kim, 2017).

Self-control of consumers is defined by Hoch and Loewenstein (1991: 493) as the "conscious effort of consumer to behave in a consistent way with the cognition, although the conditions may be appealing to behave in an inconsistent manner in behavioral settings". For instance, preferring product for satisfying a fleeting emotion and leaving out the long-term gains may indicate a lack of self-control. Thus, we can argue that the need for self-control originates from conflict between the current desires and the long-term benefits (Gonçalves, 2012). Consumer spending self-control (CSSC) focuses on the self-control of individual regarding his/her spending behavior. It refers to the consumer's ability to monitor and control his/her spending-related cognition in accordance with self-imposed norms and standards (Haws et al., 2012). Haws et al. (2012) revealed that individuals' performance on CSSC can be improved through providing the probable outcomes of their control behavior if the individual is a low scorer on CSSC, but for the high control individuals those interventions found to have no significant effect. Bearden and Haws (2012) revealed that the lack of consumers' spending self-control may give rise to the social (e.g. relationship and/or family struggles) and psychological problems (e.g. health issues, increased stress) as well as the unfavorable financial outcomes (e.g. personal bankruptcy).

Consumers sometimes behave in a way to satisfy their impulsive desires without considering the long term consequences. Then again, being motivated by long-term goals, they also may behave in a more controlled way. The responsive impulsive model (RIM) assumes that emotional and the cognitive processes work together to keep a balance most of the times (Hofmann et al., 2008). Nevertheless, it can be argued that one cannot resist his/her needs and impulses at all times; resisting some impulses like hunger and thirst for a long time is impossible. Then again, consumers still fail to resist urges that is motivated by higher-order needs and wants other than basic ones. Why cannot people resist the resistible? It was found that emotional breakdowns, lack of selfmonitoring behavior, the previous use of self-control capacity and lack of motivation to control the self (Baumeister and Vohs, 2007), the time pressure on decision making (Yim, 2017) were found to be the causes of this failure. Goal difficulty, on the other hand, can be a barrier to self-control (Davis, 2005); when consumers perceive the goal as unattainable, they tend to unleash their behavior rather than controlling it. Moreover, studies reveal that even though individuals may use self-control techniques such as mental accounting to control and manage their spending behavior, they can also manipulate and alter the basic principles situationally so that they can justify their desires (Cheema and Soman, 2006).

Self-control entails a struggle between consumer desire and willpower (Hoch and Loewenstein, 1991) that resembles the conflict between the pleasure seeking principle and the reality principle (Karlson, 2003). A certain lack of spending self-control has been associated with hedonic purchases 
and impulse buying behavior; it was found that the effect of spending self-control on impulse buying behavior is mediated by the hedonic purchases (Khuong and Tran, 2015). Consumers can cope with situations that pose a threat against their self-control by simply reducing their desires, or controlling the desire by means of willpower, such as budgeting, bundling of costs and avoiding impulsive buying. Karlson (2003) found that as the age increases and financial situation improves, the use of desire reduction strategies decreases and the use of willpower increases. He also found that while women are more likely to use desire-reduction strategies than men, men mostly try to control desire by means of willpower rather than reducing them.

Engaging in a planning behavior by setting subjective norms and self-monitoring behavior, elaborating on the future probable outcomes of the controlled and uncontrolled behavior, avoiding risky environment, conditions and factors (Haws, 2016) can help consumers to enhance their selfcontrol.

Subjective norms regarding appropriate spending behaviour may differ based on different values and priorities a mother assign to spending for their own and for their children. Norms are the informal rules that govern what is right or wrong, acceptable or unacceptable (Solomon, 2018). Since subjective norms are shaped within social and cultural contexts; Fishbein and Ajzen (1975) regard subjective norm as the effect of social environment on one's behavior. Consumers construct their behaviors while keeping an eye on the others' expectations, and also their willingness to comply with them.

Evaluations of the outcome of the spending and consequent risk expectations can highly influence individual exertion of self control in future or current consumer spending. Ajzen (1991) defined outcome evaluation as the subjective value of the result of behavior for the individual. Individuals' evaluate the outcomes of their behavior positively or negatively. Haws et al. (2012) demonstrated that consumers respond differently to external outcome elaboration prompts based on their inherent CSSC level; external stimuli enhance self-control better for low CSSC consumers.

Self-monitoring refers to means keeping track of the relevant behavior (Baumeister, 2002). It relates to the degree observing one's own spending behavior. High self-monitors are more inclined to evaluate their spending behavior in terms of how their practices and product choices match to their consumer goals. Consumers can enhance their self-control potential by utilizing several tools. Mental budgets that are defined as self-specified allowances for behaviors (Krishnamurty and Prokopec, 2010) can be utilized by consumers to monitor, control, explain and even justify their spending and enhance self-control. CSSC may change in different contexts even for the same individual; for instance, mothers may use mental budgeting for their own spending, yet they may relax their rules and trade-offs when they consider spending on their children's items.

As lack of self-control may hinder a consumers' future oriented goal, and, thus increase the feelings of consumer regret, on the other hand, excessive self-control may also cause feelings of guilt due to inaction and, thus, missing the opportunities that may provide satisfaction (Keinan and Kivets, 2008). Bartels and Urminsky (2015) revealed that consumer spending behavior is affected by the consumers' awareness of future, i.e. actively considering long-term implications of one's choices and feelings connected to the future self; consumers control their spending if they are aware of the future positive outcomes of doing so and if these outcomes are valuable for them in terms of their current and future self-definitions. Recent studies revealed that consumers have a capacity of controlling themselves, and if they use this capacity in any area, their likelihood of using it for the next time decreases (Baumeister, 2002, Muraven et al. 2006, Baumeister et al. 2008). The more consumers use their cognitive self-control capacity, the less they can regulate themselves subsequently. This depletion effect is based on the suggestion that the extent of spending selfcontrol that a consumer exerts depends on his/her cognitive control capacity to engage in highlyvalued activities (Dewitte et al., 2005). Self-control capacity, that depends on the cognitive abilities to perform well at demanding tasks, can be allocated to current and future tasks. Kelly et al. (2017) found that, rather than the previous use of self-control capacity, consumers' planned use of the 
capacity influences the amount of self-control that they exert. If consumers are planning to allocate their self-control capacity for a decision in the near future, they may relax their self-control for current tasks. Muraven et al. (2006: 536) also revealed that future expectations regarding the probable exertion of self-control also affects the self-control exertion level at the moment. If individuals are thinking that they are going to exert self-control later on, they may hesitate/prefer not to control their behavior now.

Besides, if individuals make choices through active decision making, then their self-control capacity is expected to decline gradually for every choice they face (Vohs et al. 2008). Still, studies reveal that the capacity of self-control can be expanded through regular exercising and practice; the mental strength of an individual can be improved through working on it just as in the case of physical strength (Hoyer, Maclnnis and Pieters, 2018; Sultan, Joireman and Sprott, 2012). Furthermore, since general self-control capacity of individuals may give clues for the domain specific measures (Haws et al., 2014; Redden and Haws, 2013), it can be proposed that increased self-control capacity in a specific domain can be reflected to the other domains (Baumeister et al., 2006).

\section{Self-Control: A Domain-Specific or a Dispositional Construct?}

Context refers to the circumstances and conditions that surrounds a phenomena under consideration and determine the meaning of a text and practice (Dilley, 2002). Aaskegaard and Linnet (2011) suggested that consumer research needs to pay more attention to the contexts that condition consumption practices. Recent literature has traveled far from decontextualized generalizations and accepted that recognition of context can substantially enhance the ability to make sense of the logic of consumer practice (Belk, 1975). Theories can be challenged and tested in different (emic) contexts in order to increase the explanatory power of theoretical (etic) conceptualizations (Aaskegaard and Linnet, 2011). The economic, cultural and socio-historical context of Turkey, a predominantly patriarchal and Muslim country with an emerging economy that experiences frequent crises, provides a unique case for studying consumption and self-control practices of mothers.

Starr (2007) argues that self-control is not a result of cognitive, emotional, psychological processes of and individual and it cannot be analyzed without considering social, cultural, and economic contexts. Sharma, Sivakumaran and Marshall (2011) found out that cultural context affects how consumers evaluate their self-control failure; consumers with collectivistic orientations develop diverse evaluations of their deliberate and unintended self-control failures, whereas individualistic oriented consumers do not distinguish between the two. The extent of selfcontrol may depend on the time frame; if consumers are making decisions for the future, the extent of self-control is likely to be higher (Laran, 2009).

In the relevant literature, self-control has been studied both as domain-specific state selfcontrol (Haws et al., 2014, Hoch and Loewenstein, 1991) and/or as a general personality trait (Ayadi et al., 2013; Baumeister, 2002; Ein-Gar et al., 2012). Domain specific studies embraces contextual effects; state self-control is a construct that is examined considering different contexts that accounts for more variance, such as settings, place and time (Haws, 2016, Huffmann, 2005, Haws et al., 2014). On the other hand, arguing that self-control is an inherent personality trait rather than a state that is affected by the immediate context (e.g. Muraven et al., 2006), Ein-Gar et al. (2012) revealed that the high self-control consumers delay gratification and prefer the products that offer future benefits, whereas low self-control individuals are more inclined to prefer the products that offer immediate gratification. Frögelius (2015) showed that controlling one's spending through tools such as self-scanning devices or apps, that can calculate spending each time consumer scans and puts items into the shopping basket during a supermarket visit, helps low selfcontrol individuals to decrease their expenditures, whereas the same procedure made no difference on the total amount of spending for high control consumers. Similarly, Fusaro (2008:36) 
showed that the use of debit cards can work for controlling the spending for the low self-control individuals.

Although these findings provide support for the dispositional nature of the construct, Haws et al. (2014) asserted that the dispositional self-control of individuals may also give clues for the domain-specific measures. Trying to enhance theoretical insight for the other side of the debate in the self-control literature that study self-control as a domain-specific state, Weathers and Siemens (2018) argued that dispositional self-control can only partially explain outcomes of behaviors that may change across life domains and suggested that domain-specific measurements may provide more accurate predictions. An individual can exert herself high self-control on dieting, yet the same individual may not be so successful in controlling spending in another domain.

In spite of adopting just one perspective that argues for dispositional or state dependent construct of self-control, it can be proposed that self control can be both dispositional and domainspecific. For instance, dispositionally high self-control consumers tend to control themselves every time, yet they may prefer to relax control on some occasions that do not pose them high threats, or dispositionally low self-control consumers may control their spending heavily, for instance, during economic crises.

\section{Practising Motherhood In The Marketplace and Self Control of Spending}

In consumption society, children who as socialized as consumers are supposed to develop better abilities in making their own decisions in a number of consumption domains, such as in the toys that they are going to purchase, daily outfit. As more families become child-oriented, kidfluence (Schor, 2014) increases and they may even participate in and/or influence major consumption decisions in the family, such as vacation plans, housing decisions (Wimalasiri, 2004). Their agency as consumers starts to build up after a certain age (Merhotra and Torges, 1977); according to Solomon (2018), children start to make their own consumption decisions approximately at the age of 3,5. As they grow up, their influence on major family decisions increases. Studies showed that family type influences the extent of children's consumer agency; children raised by single-parent families have more influence on major purchase decisions compared to children raised by dual-parent families (Darley and Lim, 1986).

Becoming a mother is said to be one of the most challenging transitions in women's lives; experiencing both physiological and psychological changes during this period, they try to figure out how to adapt to the new phase of life. Previous studies revealed that motherhood identity is constructed, practiced, communicated and negotiated through consumption (Clarke, 2004; Ogle, Tyner and Schofield-Tomschin, 2013; Andersen, Sørensen and Kjaer, 2008); following pregnancy, women try to construct new identity of "being a mother" by reflexively reworking, embodying and negotiating market-generated mythic, cultural and symbolic meanings that are encoded in advertisements, product and services in their social role and relations as a mother. Several studies revealed that market-generated cultural and symbolic resources can be used to cope with the identity crises, that can be experienced during transition periods (Mehta and Belk, 1991; The Voice Group, 2010; Belk, 1992; Hogg, Maclaran and Curasi, 2003; Thomsen and Sørensen, 2006; Cairns, Johnston ve MacKendrick, 2013). Being a mother is found to be an important and integral component of being a woman in Turkish culture (Sakallı-Uğurlu et al., 2018). Moreover, Duman (2011) revealed that, Turkish woman ideal is constructed as contemporary westerner supported with the hints of consumerism and being a mother, beginning from the early years of Turkish Republic. A wide range of products are introduced to market to be used on the way to get prepared for being parents; these products and services constitute a large market, in which pregnancy and motherhood experiences are largely commodified (Theodorou ve Spyrou, 2013). Due to everincreasing costs of pregnancy and childcare, most governments feel the need to conduct countrywide analyses of these expenditure items that are indeed concrete outputs of an important market (Lino et al., 2017). 
Materialistic consumption during motherhood can be problematic from the sense that it may lead women to relate maternal experiences to consumption heavily and socialize their children in consumer culture that also have dark sides. Consumption has become a criterion for women to define themselves as "good mothers"; the contemporary marketplace defines the norms of good mothering practices, i.e. which products a good mother should prefer or how much she should engage herself in "appropriate" consumption activities. The practice of motherhood through consumption of mass-marketed commodities and appropriation of their cultural, symbolic and mythic meanings may complicate mothering experiences. Marketplace ideologies and consumer culture that rest on intensive mothering -defined as mothering via utilizing all the means and all possible resources to raise their children, devote themselves psychologically and emotionally (Hays, 1996) - can prompt psychological discomfort, stress and ambivalence. For instance, in a cultural context that strictly defines the rules that differentiate good mothering from bad and assign the responsibility of raising well-adjusted children mainly to women, mothers may experience negative and mixed feelings.

On the other hand, the agency provided them by the marketplace can empower mothers in shaping children's future subjectivity and socializing them as future consumers. Recent research revealed that parents transfer their financial behavior to children (Tang, 2017). Financial selfcontrol of consumers' have strong correlations with their parents' self-control behavior.

Moreover, consumption can facilitate mothers, especially working mothers, to create an ideal family setting and help them develop their new identities (Thompson, 1996, the Voice Group, 2010). Items such as baby diapers, breast milk storage bags, breast pads, which are placed at the top of the shopping list of today's middle class mothers, can be seen as resources that facilitate self-control over daily maternal practice. Consumption objects that facilitate a better control over their life for women should be examined from a multi-faceted point of view rather labeling them as decoys or baits marketed by companies to manipulate consumers. Furthermore, spending for their children rather then for themselves seems to provide women with more satisfaction. Several studies revealed that mothers are willing to spend more money for their children than for themselves by making compromises from their own items and expenditures (Kung et al., 2014; Liu et al., 2000). Maternal love is generally seen as the natural and obvious reason why mothers willingly spend more money for their children's sake rather than their own (Kung et al., 2014). Instead of the overall household income, working mothers' personal income is found to better explain the amount of spending a mother does on behalf of her child(ren) (Banerjee, 2017).

\section{Research Methodology}

The present study aims to find out how a consumer's spending self-control changes in situations when $\mathrm{s} / \mathrm{he}$ has to decide for herself/himself and on behalf of another person. Since mothers give consumption decisions on behalf of their own and, also, their children, an analysis of mothers' consumer spending self-control may help to develop new theoretical explanations by illuminating consumer spending self-control of the same person in different contexts. Due to the budgetary limitations, an online questionnaire was used to collect data. The questionnaire was shared at various Facebook groups of mothers between September 2016-2017. Since, in Turkey, mothers are the main parent who is in charge of the consumption decisions on behalf of children, especially the ones who are 0-4 years old and have not developed a consumer agency yet (Solomon, 2018), mothers who have at least one child at these ages constituted the population.

According to various statistics (Kemp, 2016; TUIK, 2017), in 2016, \%52,6 of the Turkish population were active social media users and $37 \%$ of them were women. According to TUIK statistics, there were 5.292 .589 women who gave birth after 2013. A calculation using the percentages shows that there may be approximately 1.030 .043 mothers who have a child younger than 4 and are active social media users. Considering the standard normal deviation set at $95 \%$ confidence level and margin of error of 0.5 , the minimum sample size can be calculated as 384 (Sekaran and Bougie, 2016). A total of 400 surveys were collected through convenience sampling 
method. However, after data cleaning process, the data set consisted only 375 cases. Thus, the margin of error increased to 5.06. Considering the sampling method, sample size and collection of only online data, it can be argued that this study has its methodological limitations that may hinder generalizability of findings. Future studies should be designed with better methodologies.

Participants are composed mothers of 0-3 years of children who are members of mothers groups that are active at Facebook, and they are reached with online questionnaires. Their consumer spending self-control (CSSC) were evaluated with a scale inspired by Haws et al. (2012) and adapted for mothers' expenditures on behalf of their own and their children. Since the same scale is adapted for two different decision context a mother faces, a need to verify how well the indicator variables represent the constructs that are proposed in the factor model. The factors are named as subjective norms, self-monitoring of spending behavior and outcome evaluation. The proposed factor models and their indicator variables of each factor appear at Table 1 and Table 2.

Table 1: Items for Consumer Spending Self Control of Mothers Spending for Their Own

\begin{tabular}{|c|c|c|}
\hline \multirow{13}{*}{$\begin{array}{l}\text { CSSC } \\
\text { mother }\end{array}$} & & Self-monitoring of spending behavior \\
\hline & a1 & I know how often and for what I spend for myself \\
\hline & a2 & I monitor my spending behavior for my own expenditures closely. \\
\hline & a3 & I can make effective financial management to achieve my long-term financial goals. \\
\hline & a4 & When I go out with my friends, I always watch how much I spend. \\
\hline & & Outcome evaluation \\
\hline & a5 & I ponder if I really need it before buying anything for myself. \\
\hline & a6 & $\begin{array}{l}\text { While purchasing something for myself, I postpone my purchases until I have a certain idea } \\
\text { about the results of my purchase decisions. }\end{array}$ \\
\hline & & Subjective norms \\
\hline & a7 & I know my limits on my own expenses. \\
\hline & a8 & In social settings, I know how much I spend. \\
\hline & a9 & It is important for me to have goals for my own expenditures. \\
\hline & a10 & I am a responsible person when it comes to spending for myself. \\
\hline
\end{tabular}


Table 2: Items for Consumer Spending Self Control of Mothers Spending for Their Child(ren)

\begin{tabular}{|c|c|c|}
\hline \multirow{10}{*}{ CSSC child } & & Self-monitoring of spending behavior \\
\hline & $\mathrm{c} 1$ & I know how often and for what I spend for my child. \\
\hline & $c 2$ & I monitor my spending behavior for my child's expenses closely. \\
\hline & & Outcome evaluation \\
\hline & c3 & I ponder if she/he really needs it before buying anything for my child. \\
\hline & $\mathrm{c4}$ & $\begin{array}{l}\text { While purchasing something for my child, I postpone my purchases until I have a certain idea } \\
\text { about the results of my purchase decisions. }\end{array}$ \\
\hline & & Subjective norms \\
\hline & c5 & I know my limits on the things that I purchase for my child. \\
\hline & c6 & It is important for me to have a budget on spending for my child. \\
\hline & c7 & I am a responsible person when it comes to spending for my child. \\
\hline
\end{tabular}

\section{Research Findings}

Demographic profile of the respondents appears in Table 1 . Majority of the respondent mothers were young adults, married $(98,13 \%)$, employed $(79,73 \%)$, and live with their nuclear family (93,87\%). More than half of the respondents have undergraduate degrees $(57,33 \%)$, and have an income $3301 \mathrm{TL}$ and $9300 \mathrm{TL}$ which can be considered middle and upper-middle class (53,33\%).

Table 3: Demographic Profile of Respondents

\begin{tabular}{|c|c|c|c|c|c|}
\hline Marital Status & $\mathbf{N}$ & $\%$ & Age & $\mathbf{N}$ & $\%$ \\
\hline Single & 5 & $1.33 \%$ & $18-25$ & 20 & $5.33 \%$ \\
\hline Married & 368 & $98.13 \%$ & $26-33$ & 204 & $54.40 \%$ \\
\hline Missing & 2 & $0.53 \%$ & $34-41$ & 114 & $30.40 \%$ \\
\hline \multirow[t]{2}{*}{ Total } & 375 & 100 & $41-48$ & 3 & $0.80 \%$ \\
\hline & & & Missing & 34 & $9.07 \%$ \\
\hline Personal Income & $\mathbf{N}$ & $\%$ & Total & 375 & $100.00 \%$ \\
\hline Less than $1300 \mathrm{TL}$ & 3 & $0.80 \%$ & Education Level & $\mathbf{N}$ & $\%$ \\
\hline 1301-3300 TL & 72 & $19.20 \%$ & Primary School & 2 & $0.53 \%$ \\
\hline 3301-5300 TL & 89 & $23.73 \%$ & Secondary School & 4 & $1.07 \%$ \\
\hline 5301-7300 TL & 69 & $18.40 \%$ & High School & 53 & $14.13 \%$ \\
\hline 7301-9300 TL & 42 & $11.20 \%$ & Undergraduate & 215 & $57.33 \%$ \\
\hline
\end{tabular}




\begin{tabular}{|c|c|c|c|c|c|}
\hline 9301-11300 TL & 32 & $8.53 \%$ & Graduate & 79 & $21.07 \%$ \\
\hline 11301-13300 TL & 15 & $4.00 \%$ & Total & 375 & $100.00 \%$ \\
\hline $13301 \mathrm{TL}+$ & 37 & $9.87 \%$ & Employment Status & $\mathbf{N}$ & $\%$ \\
\hline Missing & 16 & $4.27 \%$ & Non-employed & 76 & $20.27 \%$ \\
\hline Total & 375 & $100.00 \%$ & Employed & 299 & $79.73 \%$ \\
\hline Family System & $\mathbf{N}$ & $\%$ & Total & 375 & $100.00 \%$ \\
\hline Nuclear Family & 352 & $93.87 \%$ & & & \\
\hline Extended Family & 22 & $5.87 \%$ & & & \\
\hline Total & 375 & $100.00 \%$ & & & \\
\hline
\end{tabular}

The factor models specified for consumer spending self control for mothers own spending and spending for kids are tested through confirmatory factor analysis. Self-control of mothers' spending on themselves and their children are evaluated by using the factors of subjective norm, self-monitoring of spending behavior and evaluation of outcomes. The goodness of fit indexes (Table 4) reveals that the ratio of chi square to degrees of freedom both for CSSC $_{\text {mother }}$ and CSSChild $_{\text {ch }}$ is acceptable. Hooper et al. (2008) indicated that a Goodness-of-Fit Index higher than 0,95 is satisfactory. Since the NFI and CFI values are higher than 0,90, they show a satisfactory fit of the data to the proposed factor model (Hu and Bentler, 1999:4). RMSEA is as "one of the most informative fit indices" (Diamantopoulos and Siguaw, 2000: 85). While RMSEA values between 0,08 and 0,1 indicate an acceptable fit, a RMSEA value less than 0,08 indicates a good fit (MacCallum et al., 1996). Thus, the factor model for mothers' CSSC regarding their own expenses indicates an average fit to the observed data. On the other hand, the model fit for mothers' CSSC regarding the expenses they make on behalf of their children is quite satisfactory.

Table 4: Model Fit Summary

\begin{tabular}{|l|l|l|l|l|l|}
\hline & CMIN/DF & GFI & NFI & CFI & RMSEA \\
\hline $\begin{array}{l}\text { Mothers' Consumer Spending Self Control } \\
\text { Regarding Her Own Expenditures }\end{array}$ & 3.037 & 0.961 & 0,977 & 0.983 & 0.082 \\
\hline $\begin{array}{l}\text { Mothers' Consumer Spending Self Control } \\
\text { Regarding Her Child(ren) Expenditures }\end{array}$ & 1.982 & 0.985 & 0.939 & 0.967 & 0.051 \\
\hline
\end{tabular}

Table 5 and 6 shows confirmatory factor analysis results. Since the unstandardized regression weight of the first variable of each component factor is fixed at 1, the critical ratio is not available for the first variable. Factor score weights, standardized regression weights of each variable and the significance of the results reveal that both factor structures can be explained by their indicator variables significantly. Internal consistency reliability measure (Cronbach alpha) results of factor (Table 5 and 6) reveal statistically satisfactory levels of item homogeneity, i.e. the degree that the indicator variables jointly measure the same construct is satisfactory. 
Table 5: Confirmatory Factor Analysis Results for CSSC $_{\text {mother }}$

\begin{tabular}{|c|c|c|c|c|c|c|}
\hline Factor & & $\begin{array}{l}\text { Factor Score } \\
\text { Weights }\end{array}$ & $\begin{array}{l}\text { Standardized } \\
\text { Weights }\end{array}$ & Regression & $\begin{array}{l}\text { Critical } \\
\text { Ratio }\end{array}$ & $p$ \\
\hline \multirow{4}{*}{$\begin{array}{l}\text { Self-Monitoring } \text { mother } \\
\text { Cronbach Alpha= } 0,845\end{array}$} & a1 & .176 & .784 & & & \\
\hline & $a 2$ & .159 & .791 & & 26.911 & 0,001 \\
\hline & a3 & .054 & .679 & & 13.833 & 0,001 \\
\hline & a4 & .070 & .686 & & 13.346 & 0,001 \\
\hline \multirow{2}{*}{ 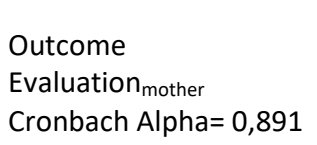 } & a5 & .461 & .930 & & & \\
\hline & a6 & .137 & .851 & & 24.142 & 0,001 \\
\hline \multirow{4}{*}{$\begin{array}{l}\text { Subjective Norms mother } \\
\text { Cronbach Alpha }=0,920\end{array}$} & a7 & .330 & .927 & & & \\
\hline & a8 & .057 & .796 & & 21.470 & 0,001 \\
\hline & a9 & .242 & .851 & & 20.757 & 0,001 \\
\hline & a10 & .126 & .905 & & 29.633 & 0,001 \\
\hline
\end{tabular}

Table 6: Confirmatory Factor Analysis Results for CSSC $_{\text {child }}$

\begin{tabular}{|c|c|c|c|c|c|}
\hline Factor & & $\begin{array}{l}\text { Factor Score } \\
\text { Weights }\end{array}$ & $\begin{array}{l}\text { Standardized } \\
\text { Regression Weights }\end{array}$ & Critical Ratio & $p$ \\
\hline \multirow{2}{*}{$\begin{array}{l}\text { Self-Monitoring } \\
\text { Cronbild } \\
\text { Croch Alpha }=0,917\end{array}$} & $\mathrm{c} 1$ & .548 & .890 & & \\
\hline & c2 & .246 & .953 & 24.176 & 0,001 \\
\hline \multirow{2}{*}{$\begin{array}{l}\text { Outcome Evaluation } \\
\text { child } \\
\text { Cronbach Alpha }=0,860\end{array}$} & c3 & .308 & .886 & & \\
\hline & c4 & .247 & .859 & 21.621 & 0,001 \\
\hline \multirow{3}{*}{$\begin{array}{l}\text { Subjective Norms } \text { child } \\
\text { Cronbach Alpha }=0,882\end{array}$} & c5 & 159, & .888 & & \\
\hline & c6 & .134 & .710 & 15.848 & 0,001 \\
\hline & c7 & .241 & .881 & 22.774 & 0,001 \\
\hline
\end{tabular}

After confirming the proposed factor models and realizing that each construct is reliably significant, a paired samples t-test is conducted to find out if a mother's spending self-control changes in situations when $\mathrm{s} /$ he has to decide for herself and on behalf of her children. The main hypothesis and sub-hypotheses are as follows:

H1: There is a statistically significant difference between mothers' consumer spending selfcontrol regarding their own and their children's expenses.

H1a: There is a statistically significant difference between mothers' "self- monitoring of spending behavior" regarding their own and their children's expenses. 
H1b: There is a statistically significant difference between mothers' "evaluations of outcome" of spending of their own and on behalf of their children.

H1c: There is a statistically significant difference between mothers' "subjective norms" that apply for behavior of spending of their own and on behalf of their children.

The results of paired samples t-tests reveal significant differences in terms of "subjective norms" factor (Table 7). The factor of "subjective norms" which signifies the level of awareness and responsibility a mother has during her spending behavior found to be significantly higher for expenditures on behalf of her children than spending for her own. This finding supports Thompson's (1996) idea of "caring consumption": mothers' consumer behavior is a reflection of their caring orientation in their personal relationships. When the decision related to spending on behalf of children, consumption becomes an integral part of maternal responsibility (Takahashi, 2014). Therefore, the level of responsibility and awareness felt by mothers turns out to be higher for the expenditures they make on behalf of their children compared to their own. This finding can also be seen as in line with the intensive mothering ideology (Hays, 1996) which embrace a childcentered rearing practice that implies that a mother should engage herself in "caring" consumption activities on behalf of her children and prioritize their needs and wants more than her own.

The results of paired samples t-tests also reveal significant differences in terms of "evaluation of outcome" factor (Table 7). "Outcome evaluation", as one of the major factors determining consumer spending self control is found to be significantly higher for mothers' own expenditures compared to their spending on behalf of their children. In addition to the higher we level of responsibility and awareness felt by mothers when they consider their spending on behalf of their children, they also problematize the actual results of their own spending more than the outcomes of the spending that they make on behalf of their kids. One reason for that may be the "good mothering" rhetoric as a reflection of dominant marketplace ideology of intensive mothering that calls for everyday consumption of specific products and services to be a "good" mother (Nguyen, Harman and Cappelini, 2017; DeLaat and Bauman, 2014). These results support the findings of other studies that propose that mothers are willing to spend more money for their children than for themselves by making compromises from their own items and expenditures (Kung et al., 2014; Liu et al., 2000).

Table 7: Paired Samples t-test Results for Difference Between CSSC $_{\text {mother }}$ and CSSC $_{\text {child }}$ Factors

\begin{tabular}{|c|c|c|c|c|c|c|}
\hline & & $\mathrm{N}$ & Mean & $\begin{array}{l}\text { Std. } \\
\text { Variation }\end{array}$ & Mean Difference & P (two-sided) \\
\hline \multirow{2}{*}{$\mathrm{H} 1 \mathrm{a}$} & Self-Monitoring mother & 375 & 4.81 & 1.65 & \multirow{2}{*}{-.09} & \multirow{2}{*}{.258} \\
\hline & Self-Monitoring child & 375 & 4.90 & 1.86 & & \\
\hline \multirow{2}{*}{$\mathrm{H} 1 \mathrm{~b}$} & $\begin{array}{l}\text { Outcome Evaluation } \\
\text { mother }\end{array}$ & 375 & 5.00 & 1.91 & \multirow[t]{2}{*}{.66} & \multirow[t]{2}{*}{.000} \\
\hline & Outcome Evaluation child & 375 & 4.34 & 1.87 & & \\
\hline \multirow{2}{*}{$\mathrm{H} 1 \mathrm{c}$} & Subjective Norms mother & 375 & 5.10 & 1.73 & \multirow{2}{*}{-1.83} & \multirow{2}{*}{.000} \\
\hline & Subjective Norms child & 375 & 6.93 & 2.74 & & \\
\hline
\end{tabular}

On the other hand, mothers' self-monitoring behavior does not significantly differ across spending contexts that they consider for their own and their child(ren) needs and wants (Table 7). Mothers are monitoring their spending behavior for their own and for their child(ren) in a similar manner. The reason for this similarity may be that mothers are carrying the full responsibility of 
their spending and therefore they are monitoring their spending behavior in a similar way no matter it is for her own or her children.

\section{Conclusion}

Although there are studies that reveal how consumer self-control varies across different domains, there still remains a lack of research that analyze how a consumer's self-control of spending may change in situations when the decision-maker and users are not the same person. Since mothers make consumption decisions on behalf of their own and, also, their children, an analysis of mothers' consumer spending self-control may help to develop new theoretical explanations by shedding a light on consumer spending self-control of the individual depending on different modes of relation to oneself and others, and in different contexts.

The findings revealed that mothers' consumer spending self control for mothers own spending and for children's spending can be evaluated using three indicative factors that can be labeled as "self- monitoring of spending behavior", "outcome evaluation" and "subjective norms". Hypotheses tests that are conducted to find out whether there's a significant difference between these factors that indicate mothers' consumer spending self control regarding their own expenditures and the expenditures they make on behalf of their children, revealed that the "subjective norms" and "outcome evaluation" factors of significantly differ across different contexts experienced by a mother. The level of subjective norms of a mother turns out to be higher for the expenditures they make on behalf of their children compared to their own. They feel higher responsibility for their spending decisions. Furthermore, they problematize the actual results of their own spending more than the outcomes of the spending that they make on behalf of their kids. The reason may be attributed to "good/intensive mothering" ideology. These results support the notion that mothers are willing to spend more money for their children than for themselves by making compromises from their own items and expenditures. On the other hand, it was also found that mothers are monitoring their spending behavior that relates to their own and, also, their child(ren) needs and wants. It can be proposed that the lack of difference may be due to the reason that mothers have the full responsibility for both spending, and therefore, they are monitoring their spending behavior in a similar way no matter it is for her own or her children.

Mothering, when interpreted as a resource-depleting and exhausting workload on women, can drain the self-control capacity; women start to control themselves in many domains once they get pregnant. They limit the amount of alcohol intake, they try to stay away from smoking, avoid junk food alternatives; i.e. prefer virtue over vice. Thus, their exerted level of self-control on spending may be relatively lower due to the reason that they may have spent their control capacities in other domains. Future research may focus on self-control depletion areas for mothers and compare mothers' self control capacity for several domains.

It can be stated that the most important contribution of the study to the literature is that the research demonstrates that, in different contexts, the same person may have different experiences in terms of the indicative factors of consumers' spending self control. On the other hand, considering the sampling method, sample size and collection of only online data, it can be argued that this study has its methodological limitations that may hinder generalizability of findings. Future studies should be designed with better methodologies.

\section{References}

Ajzen, I. (1991). The Theory of Planned Behavior. Organizational Behavior and Human Decision Processes, 50(2), 179-211.

Andersen, L. P., Sørensen, E. and Kjaer, M. B. (2008). Not too Conspicuous, Mothers' Consumption of Baby Clothing, in E-European Advances in Consumer Research Vol. (8), eds. Stefania Borghini, Mary Ann McGrath, and Cele Otnes, Duluth, pp: 94-98. MN : Association for Consumer Research. 
Arnould, Eric J. and Thompson C. J. (2005). Consumer Culture Theory (CCT): Twenty Years of Research. Journal of Consumer Research, 31 (March), 868-882.

Arnould, Eric J. and Price, L. L. (2000). Authenticating Acts and Authoritative Performances: Questing for Self and Community, in The Why of Consumption: Contemporary Perspectives on Consumers Motives, Goals, and Desires, eds. S. Ratneshwar, D. G. Mick, C. Huffman, pp: 140-163. London: Routledge.

Askegaard, S., and Linnet, J. T. (2011). Towards an Epistemology of Consumer Culture Theory. Marketing Theory, 11(4), 381-404.

Ayadi, N., Giraud, M. and Gonzalez, C. (2013). An Investigation of Consumers' Self-Control Mechanisms When Confronted with Repeated Purchase Temptations: Evidence From Online Private Sales. Journal of Retailing and Consumer Services, 20 (2013), 272-281.

Banerjee, M. S. (2017). A Study on Mothers' Buying Behavior for Their Kids: A Mumbai Perspective. International Journal of Research in Finance and Marketing, 7(6), 101-118. http://euroasiapub.org/wp-content/uploads/2017/07/11FMJune-5063.pdf

Banister E. and Hogg, M. (2006). The Self-Determination Processes of New Mothers, in Stefania Borghini, Mary Ann McGrath, and Cele Otnes (Eds.), E - European Advances in Consumer Research, 8 (pp. 399-401). MN : Association for Consumer Research.

Bartels, D. M., and Urminsky, O. (2015). To Know And To Care: How Awareness And Valuation of the Future Jointly Shape Consumer Spending. Journal of Consumer Research, 41(6), 14691485.

Baumeister, R. F. (2002). Yielding to Temptation: Self-Control Failure, Impulsive Purchasing and Consumer Behavior. Journal of Consumer Research, 28(4), 670-676.

Baumeister, R. F. and Vohs, K. D. (2007). Self-Regulation, Ego Depletion, and Motivation. Social and Personality Psychology Compass 1/1, 115-128.

Baumeister, R. F., Gailliot, M., DeWall, N. and Oaten, M. (2006). Self-Regulation and Personality: How Interventions Increase Regulatory Success, and How Depletion Moderates the Effects of Traits on Behavior. Journal of Personality, 74(6), 1773-1802.

Baumeister, R. F., Sparks, E. A., Stillman, T. F. and Vohs, K. D. (2008). Free Will in Consumer Behavior: Self-Control, Ego Depletion, and Choice. Journal of Consumer Psychology, 18 (2008), 4-13.

Bearden, W. O. and Haws, K. L. (2012). How Low Spending Control Harms Consumers. Journal of the Academy of Marketing Science, 40(1), 181-193.

Belk, R. W. (1975). Situational Variables and Consumer Behavior. Journal of Consumer Research, 2 (3), 157-164.

Belk, R. W. (1988). Possessions and the Extended Self. Journal of Consumer Research, 15(2), 139168.

Belk, R. W. (1992). Moving Possessions: An Analysis Based on Personal Documents from the 18471869 Mormon Migration, Journal of Consumer Research, 19(3), 339-361.

Bourdieu, P. (1977), Outline of a Theory of Practice, Cambridge, England: Cambridge University Press

Cairns, K., Johnston J. and MacKendrick, N. (2013). Feeding the "organic child": Mothering through ethical Consumption. Journal of Consumer Culture, 13(2), 97-118. 
Cheema, A. and Soman, D. (2006). Malleable Mental Accounting: The Effect of Flexibility on the Justification of Attractive Spending and Consumption Decisions. Journal of Consumer Psychology, 16(1), 33-44.

Clarke, A. (2004). Maternity and Materiality: Becoming Mother in Consumer Culture, in Consuming Motherhood, eds. Janelle S. Taylor, Linda L. Layne, and Danielle F. Wozniak. Pp: 55-71. New Jersey: Rutgers University Press.

Darley, W. K., \& Lim, J. S. (1986). Family decision making in leisure time activities: An exploratory investigation of the impact of locus of control, child age influence factor and parental type on perceived child influence. In R. J. Lutz (Ed.), Advances in consumer research, 13 (pp. 370-374). Provo, UT: Utah, Association for Consumer Research.

Davis, S. W. (2005). The (In)Effectiveness of Self-Control Interventions. Dissertation submitted to the Office of Graduate and Professional Studies of Texas A\&M University.

Dewitte, S., Pandelaere, M., Briers, B. and Warlop, L. (2005). Cognitive Load has Negative After Effects on Consumer Decision Making (October 2005). Working paper DOI:10.2139

Diamantopoulos, A. and Siguaw, J.A. (2000). Introducing LISREL. London: Sage

Dilley, R. M. (2002). The Problem of Context in Social and Cultural Anthropology. Language \& Communication, 22(4), 437-456.

Duman, D. (2011). Gender politics in Turkey and the role of women's magazines: a critical outlook on the early republican era, Hacettepe Üniversitesi Edebiyat Fakültesi Dergisi, 28(1), 7592.

Ein-Gar, D., Goldenberg, J. and Sagiv, L. (2012). The role of consumer self-control in the consumption of virtue products, International Journal of Research in Marketing, 29(2), 123-133.

Fishbein, M., and Ajzen, I. (1975). Belief, Attitude, Intention and Behavior: An Introduction to Theory and Research. Reading, MA: Addison-Wesley.

Frögelius, S. (2015). Mobile Self-scanning -Increasing Self-Control?. http://lup.lub.lu.se/studentpapers/record/7356726. Date of access: May 20th, 2019.

Fusaro, M. A. (2008). Debit vs Credit: A Model of Self-Control with Evidence From Checking Accounts. Working Paper, (East Carolina University, 2008).

Gonçalves, D. (2012). Self-Regulation: Consumer Non-Behavior. Psychology Today. https://www.psychologytoday.com/us/blog/there-are-free-lunches/201201/selfregulation-consumer-non-behavior Date of access: March $5^{\text {th }}, 2019$.

Haws, K. L. (2016) Enhancing Self-Control in Consumer Decisions. Current Opinion in Psychology, 10, 118-123.

Haws, K. L., Bearden, W. O. and Nenkov, G. Y. (2012). Consumer Spending Self Control Effectiveness and Outcome Elaboration Prompts. Journal of the Academy of Marketing Science, 40(5), 695-710.

Haws, K. L., Davis, S., Dholakia, U. and Yoon, Y. (2014). Control Over What? Assessing General and Domain- Specific Self-Control, in Cotte J. and Wood (Eds.) NA - Advances in Consumer Research, 42 ,pp. 506-507. Duluth, MN : Association for Consumer Research.

Hays, S. (1996). The Cultural Contradictions of Motherhood. New Haven: Yale University.

Hoch, S. J. and Loewenstein, G. F. (1991). Time-Inconsistent Preferences and Consumer SelfControl. Journal of Consumer Research, 17(3), 492-507. 
Hofmann, W., Strack, F., and Deutsch, R. (2008). Free To Buy? Explaining Self-Control and Impulse in Consumer Behavior. Journal of Consumer Psychology 18 (1), 22-26.

Hogg, M.K., Maclaran, P. and Curasi, C. F. (2003). Consumption, Role Transitions and the ReConstruction of the Self: an Exploratory Study of Social Capital Within the Context of Transitional Consumers, in Darach Turley and Stephen Brown (Eds.) E - European Advances in Consumer Research, Vol. (6), 258-262. Provo, UT : Association for Consumer Research.

Hooper, D., Coughlan, J. and Mullen, M. R. (2008). Structural Equation Modelling: Guidelines for Determining Model Fit. The Electronic Journal of Business Research Methods, 6(1), $53-60$. http://www.ejbrm.com/vol6/v6-i1/v6-i1-papers.htm

Hoyer, W. D., Maclnnis, D. J. and Pieters, R. (2018). Consumer Behavior. 7th Edition. Boston: Cengage Learning.

Hu, Li-tze and Bentler, Peter M. (1999) Cutoff Criteria for Fit Indexes in Covariance Structure Analysis: Conventional Criteria versus New Alternatives. Structural Equation Modeling: A Multidisciplinary Journal, 6(1), 1-55.

Hufmann, D. and Barenstein, M. (2005). A Monthly Struggle for Self-Control? Hyperbolic Discounting, Mental Accounting, and the Fall in Consumption Between Paydays. IZA Discussion Paper, No. 1430 in partial fulfillment of the requirements for the degree of DOCTOR OF PHILOSOPHY.

Hughes M.U., Kaigler-Walker K. and Bendoni W. (2015) Young Children as Parents' Extended Selves, in Robinson, Jr. L. (Ed.) Marketing Dynamism \& Sustainability: Things Change, Things Stay the Same.... Developments in Marketing Science: Proceedings of the Academy of Marketing Science, pp. 600-607. Cham: Springer.

Karlsson, N. (2003). Consumer Self-Control Strategies: An Empirical Study of Their Structure and Determinants. Journal of Consumer Policy, 26, 23-41.

Keinan, A. and Kivetz, R. (2008). Remedying Hyperopia: The Effects of Self- Control Regret on Consumer Behavior. Journal of Marketing Research, 45, 676-689.

Kelly, C.L., Crawford, T .J., Gowen, E., Richardson, K. and Sünram-Lea, S.I. (2017). A Temporary Deficiency in Self-Control: Can Heightened Motivation Overcome This Effect? Psychophysiology, 54(5), 773-779.

Kemp, S. (2016). Digital 2016: Turkey. https://datareportal.com/reports/digital-2016-turkey. Date of access: May 15th, 2019.

Khuong, M. N. and Tran, T. B. (2015). Factors Affecting Impulse Buying toward Fashion Products in Ho Chi Minh City - A Mediation Analysis of Hedonic Purchase. International Journal of Trade, Economics and Finance, 6(4), 223-229.

Krishnamurthy, P. and Prokopec, S. (2010). Resisting That Triple-Chocolate Cake: Mental Budgets and Self-Control. Journal of Consumer Research, 37(1), 68- 79.

Kung, C., Ou, Y., Yeh, D. and Wang, C. (2014). The Neural Substrate of Maternal Love in Shopping: Mothers' Willingness to Pay for Her Child Vs. for Herself: An Fmrı Study. 2014 International Conference on Orange Technologies, 137-140.

Laran, J. (2009). Choosing Your Future: Temporal Distance and the Balance between Self-Control and Indulgence. Journal of Consumer Research, 36(6), 1002-1015.

Lino, M., Kuczynski, K., Rodriguez, N., and Schap, T. (2017). Expenditures on Children by Families, 2015. Miscellaneous Publication No. 1528-2015. U.S. Department of Agriculture, Center for Nutrition Policy and Promotion. 
Liu, J.T., Hammitt, J. K., Wang, J.R. and Liu J.L., (2000). Mother's Willingness To Pay For Her Own And Her Child's Health: A Contingent Valuation Study İn Taiwan. Health Economics, 9(4), 319-326.

MacCallum, R. C., Browne, M. W., and Sugawara, H. M. (1996). Power Analysis and Determination of Sample Size for Covariance Structure Modeling. Psychological Methods, 1(2), 130-149.

McNeill, L. and Graham, T. (2014). Mother's Choice: An Exploration of Extended Self in Infant Clothing Consumption. Journal of Consumer Behaviour, 13, 403-410.

Mehta, R., and Belk, R. W. (1991). Artifacts, identity, and transition: Favorite possessions of Indians and Indian immigrants to the United States. Journal of Consumer Research, 17(4), 398-411.

Muraven, M., Shmueli, D. and Burkley, E. (2006). Conserving Self-Control Strength. Journal of Personality and Social Psychology, 91(3), 524-537.

Nguyen, KL-P, Harman, V. and Cappellini, B. (2017). Playing with Class: Middle-Class Intensive Mothering and the Consumption of Children's Toys in Vietnam. International Journal of Consumer Studies. 41(5), 449- 456.

Ogle, J. P., Tyner, K. E. and Schofield-Tomschin, S. (2013). The role of maternity dress consumption in shaping the self and identity during the liminal transition of pregnancy. Journal of Consumer Culture, 13(2), 119-139.

Özhan-Dedeoğlu, A. (2010). Discourses of Motherhood and Consumption Practices of Turkish Mothers. Business and Economics Research Journal, 1(3), 296-311.

Redden, J. P. and Haws, K. L. (2013). Healthy Satiation: The Role of Decreasing Desire in Effective Self-Control. Journal of Consumer Research, 39(5), 1100-1114.

Sakallı-Uğurlu, N., Türkoğlu, B. and Kuzlak, A. (2018). How are women and man perceived? Structure of gender stereotypes in contemporary Turkey. Nesne, 6(13), 309-336.

Schor, J. B. (2014). Born to Buy: The Commercialized Child and the New Consumer Culture. New York: Scribner.

Sekaran, U., and Bougie, R. (2016). Research Methods For Business: A Skill Building Approach. John Wiley and Sons.

Sela, A., Berger, J. and Kim, J. (2017). How Self-Control Shapes the Meaning of Choice, Journal of Consumer Research, 44(4), 724-737.

Sharma, P., Sivakumaran, B. and Marshall, R. (2011). Deliberate Self-Indulgence versus Involuntary Loss of Self-Control: Toward a Robust Cross-Cultural Consumer Impulsiveness Scale. Journal of International Consumer Marketing. 23 (3-4), 229-245.

Silhouette-Dercourt, V. and Lassus, C. (2016). Shopping For Kids' Luxury Brands: Young Mothers' Identity Quest In Retail Spaces. International Journal of Retail \& Distribution Management, 44(11), 1084-1099.

Solomon, M. R. (2018). Consumer Behavior: Buying, Having and Being. Essex: Pearson.

Starr, M. (2007). Saving, Spending, and Self-Control: Cognition versus Consumer Culture. Review of Radical Political Economics, 39(2), 214-229.

Sultan, A., Joireman, J. \& Sprott, D. (2012). Building Consumer Self-Control: The Effect of SelfControl Exercises on Impulse Buying Urges. Marketing Letters. 23(1), 61-72.

Takahashi, M. (2014). Ideological Dilemmas: Constructing Motherhood Through Caring Consumption In Japan. Young Consumers, 15(1), 84-93. 
Tang, N. (2017). Like Father Like Son: How Does Parents' Financial Behavior Affect Their Children's Financial Behavior? The Journal of Consumer Affairs, 51(2), 284-311.

The Voice Group (2010), Buying into Motherhood? Problematic consumption and ambivalence in transitional phases, Consumption, Markets and Culture, 13(4), 373-397.

Theodorou, E. ve Spyrou, S. (2013). Motherhood in Utero: Consuming Away Anxiety. Journal of Consumer Culture, 13(2),79-96.

Thomsen, T. U. and Sørensen, E. (2006). The First Four-wheeled Status Symbol: Pram Consumption as a Vehicle for the Construction of Motherhood Identity, Journal of Marketing Management, 22(9/10), 907-927.

Thompson, C. J. (1996). Caring Consumers: Gendered Consumption Meanings and the Juggling Lifestyle, Journal of Consumer Research, 22 (4), 388-407.

TUIK (2017). Website of Turkish Statistical Institution. Accessed via: http://www.tuik.gov.tr

Tuk, M. A., Zhang, K., and Sweldens, S. (2015). The propagation of self-control: Self-control in one domain simultaneously improves self-control in other domains. Journal of Experimental Psychology: General, 144(3), 639-654.

Vohs, K. D., Baumeister, R. F., Schmeichel, B. J., Twenge, J. M., Nelson, N. M. and Tice, D. M. (2008). Making Choices Impairs Subsequent Self-Control: A Limited-Resource Account of Decision Making, Self-Regulation, and Active Initiative. Journal of Personality and Social Psychology, 94(5), 883-898.

Weathers, D. and Siemens, J. C. (2018). Measures of State Self-Control and Its Causes for Trackable Activities. Journal of Business Research, 93 (2018), 1-11.

Wimalasiri, J. S. (2004). A Cross-National Study on Children's Purchasing Behavior and Parental Response. Journal of Consumer Marketing, 21(4), 274-284.

Yim, M. Y. C. (2017). When Shoppers Don't Have Enough Self-Control Resources: Applying the Strength Model of Self- Control. Journal of Consumer Marketing, 34(4), 328-337. 